\title{
Influence of hydroelectric power station on flood situation and modeling of hydrological characteristics
}

\author{
Yaroslav Grebnev ${ }^{1 *}$, Alexander Moskalev ${ }^{1}$, and Anatoly Vershkov ${ }^{1}$ \\ ${ }^{1}$ Siberian Federal University, engineer at the Forecasting Department of the Central Office of the \\ Russian Ministry of Emergency Situations in Krasnoyarsk Krai, Russia
}

\begin{abstract}
The paper presents the results of modelling the process of flooding the territories of settlements during the rise of flood water in view of the hydrological and climatic characteristics of the Yenisey River. The effectiveness of the model, which takes into account many factors, has been assessed in the course of rising flood water on the Yenisey River in 2020.
\end{abstract}

\section{Introduction}

Numerous natural disasters happen in the environment, the danger which is in focus of our study is natural floods related to the geographical location of settlements and the hydrological condition of water bodies [1,2]. One of the most pressing problems for the settlements in the vicinity of large water bodies is the development of flood and waterlogging forecasting methods for protection of the river banks and other preventive measures [3].

The catastrophic effects caused by flooding can be addressed only in terms of reducing the severity of flooding effects [4]. The situation is aggravated by the increasing man-made pressure on nature [5]. For instance, given the impact of the cascade of hydroelectric power plants on the Yenisey River, the nature of flooding in residential areas changes during rising flood water [6]. Issues of forecasting and effective elimination of risk-related emergencies are an integral part of the problem of population safety and welfare [7].

During spring snowmelt flood, regular flooding occurs near Yartsevo on the Yenisey River in the Krasnoyarsk Krai, which causes significant damage to residents of the settlement and its economic facilities [8]. In order to organise preventive measures in this area, it is important to develop a model for the settlement flooding. One of the effective ways of solving this problem is to use modern information technologies, scientific and technical solutions realised in systems for automatic monitoring and prevention of emergency situations [9].

\section{Materials and methods}

In order to handle the problem of developing preventive measures and defining flood zones, it is best to use software whose algorithms are based on mathematical modelling methods, as

*Corresponding author: yaroslav.grebnev@gmail.com 
they enable solving problems with many variables, taking into account environmental impact factors [10].

To calculate the water levels of the given water supply of the Yenisey River near Yartsevo, the HEC-RAS software package (www.hec.usace.army.mil) and the ArcView HEC-GEORAS extension were used to solve a one-dimensional problem of steady or unsteady water movement based on the St. Venant equations [11].

On the basis of engineering and hydrographic works performed at the observation network point of the Federal State Budgetary Institution "Middle Siberian Department for Hydrometeorology and Environmental Monitoring" of the Yenisey within Yartsevo in the last decade of March 2019, there were collected data on water level markings of estimated capacity and values of high water in this area. Based on the results of engineering and hydrographic work, a two-dimensional digital relief model was constructed. Figure 1 shows the digital relief model for the area adjacent to the Yenisey River within Yartsevo boundaries.

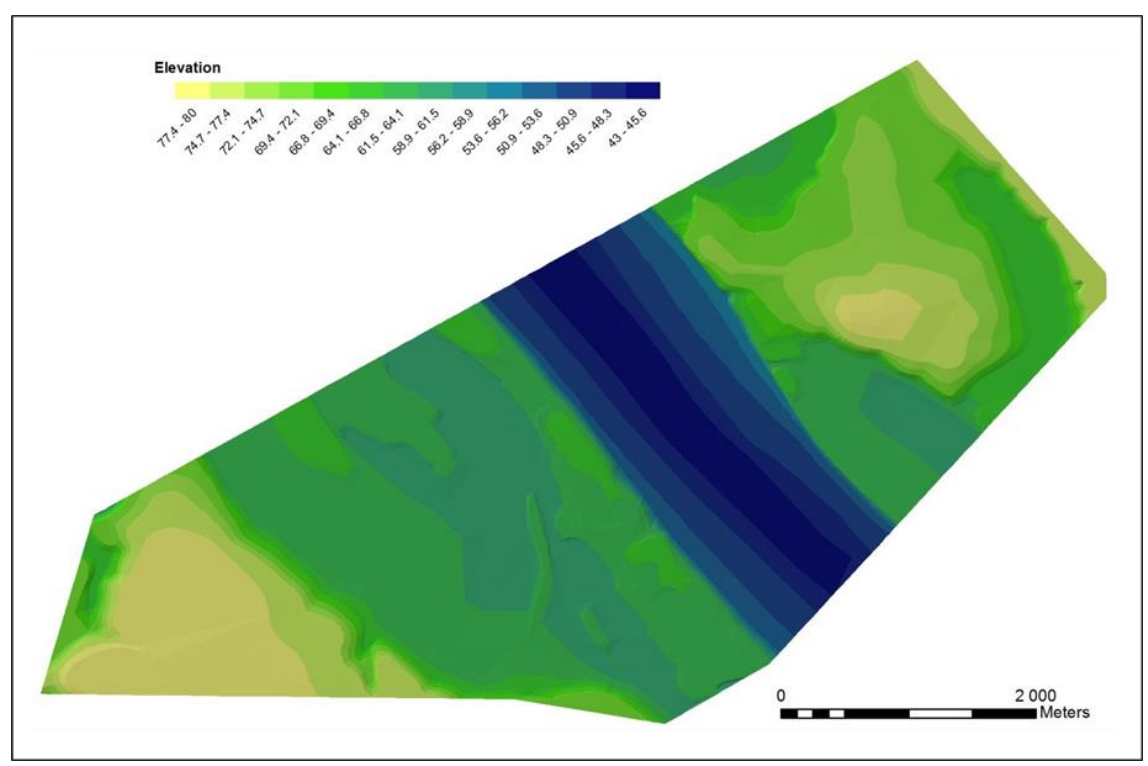

Fig. 1. Digital relief model of the area adjacent to the Yenisey River in the section of Yartsevo.

In this work, the software package MODFLOW (McDonald M.G. et al, 2003) [12] was used to model groundwater movement in Aquaveo GMS (Groundwater Modeling System) and Simcore PMWIN (Processing ModFlow) environments [13]. The aquifer in the program is schematized as a multilayer, bounded by contour, fed by precipitation infiltration and water inflows across its boundaries.

In order to calculate the groundwater level, a three-dimensional mathematical model of a given section was constructed, with stratigraphy of the layers with a regard to drilling data at specific locations. Numerical solutions to the filtration equation based on data from the intensive water exchange zone were produced by using a method generally accepted in hydrogeology [14].

PCGN solution method (the Preconditioned Conjugate Gradient Solver with Improved Nonlinear Control package) was used in the calculations.

\section{Results and discussion}

To solve the problem of modelling flooded areas in the area of the Yartsevo settlement, the first stage was marked by the collection of information required for modelling. This stage 
included obtaining and analysing materials on flooding and waterlogging of the investigated area during the period of observation from 1937 to 2019. The analysis of baseline information resulted in a summary table of characteristic values of fluctuations in the Yenisey River level at the line gauges of the hydrological post in the Yartsevo (Table 1); actual waterlogging and flooding zones were assessed and the task of hydrological work and measures against floods was set. In order to model surface water movement and flooding, there were carried out calculations using a method generally accepted in hydrogeology. On the basis of hydrological calculations, the costs of ensuring the required flow and the boundary conditions of the modelling were determined. Modelling was made using a digital relief model and maps of surface characteristics. It should be noted that a special feature of the modelling task in Yartsevo settlement is that there are two maximum levels (winter and spring) observed in different years, and there is also considerable uncertainty about the beginning of the winter increase in levels due to the operation of the Krasnoyarsk Hydro Power Plant. Following the construction of the Krasnoyarsk Hydro Power Plant dam in 1969, the highest spring flood was observed in 2001. At the first stage of the modelling task, a schedule was drawn up to show the maximum values of the river level rise in the area of Yartsevo, depending on the year; to build the graph data from 1973 to 2012 were taken. Then characteristic fluctuations of the Yenisey River level at the hydrological post in the Yartsevo settlement were calculated (shown in Table 1).

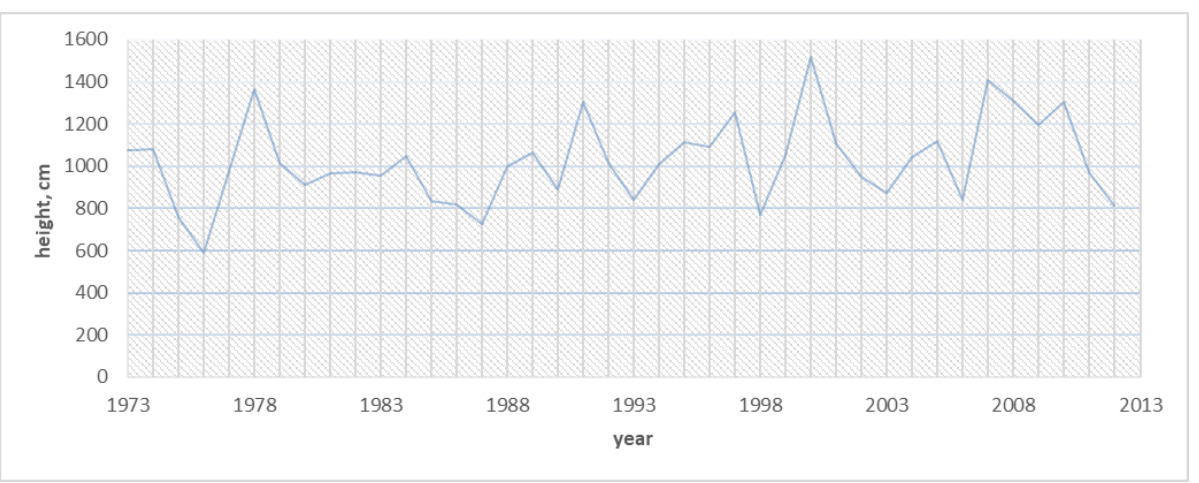

Fig. 2. Maximum values of the river level rise in the area of the Yartsevo settlement, depending on the year.

Table 1. Characteristic fluctuations of the levels of the Yenisey River at the line gauges of hydrological posts in Yartsevo (1982, 2001-2002, 2007).

\begin{tabular}{|c|c|c|c|c|}
\hline \multirow[b]{2}{*}{ Date } & \multirow[b]{2}{*}{ Day } & \multicolumn{2}{|c|}{ Yartsevo } & \multirow{2}{*}{$\begin{array}{c}\text { Water } \\
\text { discharge, } \mathrm{m}^{3 / \mathrm{s}}\end{array}$} \\
\hline & & $\begin{array}{l}\text { Exceeding "0" of the } \\
\text { hydrological post, cm }\end{array}$ & $\begin{array}{c}\text { Level, m (Baltic } \\
\text { system) }\end{array}$ & \\
\hline 1.01 & 1 & 973 & 51.36 & 26069 \\
\hline 22.03 & 81 & 973 & 51.36 & 26069 \\
\hline 7.04 & 97 & 704 & 48.67 & 16744 \\
\hline 11.05 & 131 & 772 & 49.35 & 19020 \\
\hline 18.05 & 138 & 1166 & 53.29 & 33380 \\
\hline 14.06 & 165 & 427 & 45.90 & 8469 \\
\hline 18.12 & 352 & 287 & 44.50 & 4923 \\
\hline 19.12 & 353 & 708 & 48.71 & 16875 \\
\hline
\end{tabular}

At the second stage, a curve of maximum level values for the winter rise and spring flood for the hydrological post in Yartsevo was drawn to determine the dependence of flood levels with revealing maximum observable values (Figure 3). Moreover, to account for the 
congestion of water level rise during the typical period of congestion 09.05-11.05 (average duration of 3 days) characteristic values of levels have been added, for the settlement of Yartsevo (Table 2).

Table 2. Characteristic fluctuations of the levels of the Yenisey River at the line gauges of hydrological posts in Yartsevo (1982, 2001-2002, 2007).

\begin{tabular}{|c|c|c|c|}
\hline Date & Day & $\begin{array}{c}\text { Exceeding "0" of the } \\
\text { hydrological post, cm }\end{array}$ & $\begin{array}{c}\text { Level, m (Baltic } \\
\text { system) }\end{array}$ \\
\hline 1.01 & 1 & 1172 & 53.35 \\
\hline 22.03 & 81 & 1172 & 53.35 \\
\hline 7.04 & 97 & 704 & 48.67 \\
\hline 8.05 & 128 & 766 & 49.29 \\
\hline 9.05 & 129 & 1622 & 57.85 \\
\hline 10.05 & 131 & 1622 & 57.85 \\
\hline 11.05 & 131 & 1622 & 57.85 \\
\hline 12.05 & 132 & 829 & 49.92 \\
\hline 18.05 & 138 & 1282 & 54.45 \\
\hline 14.06 & 165 & 427 & 45.90 \\
\hline 18.12 & 352 & 287 & 44.50 \\
\hline 19.12 & 353 & 708 & 48.71 \\
\hline
\end{tabular}

Figure 3 presents the dependence of the average level of water rise during the year (using monthly average observation data from May 1973 to December 2012).

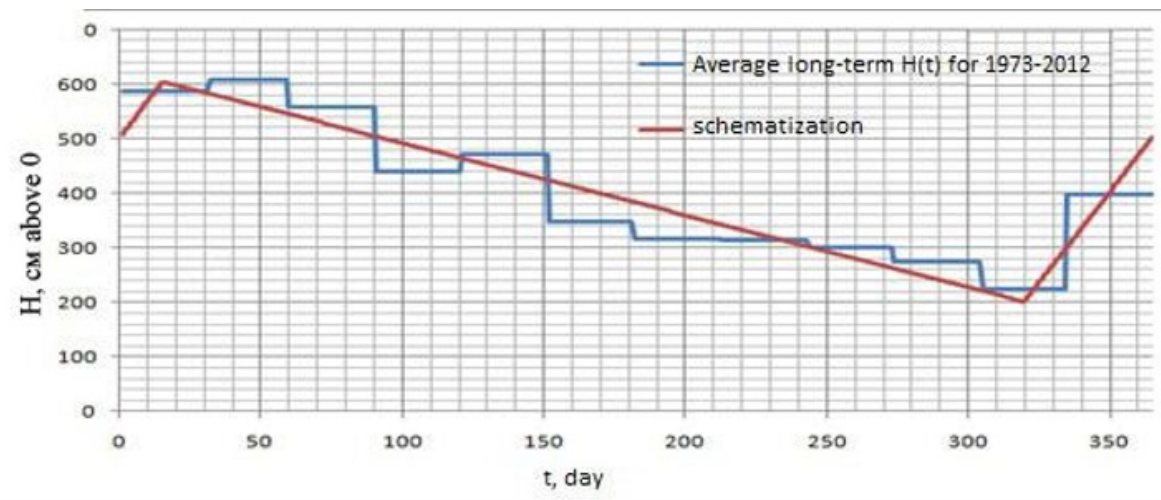

Fig. 3. Dependence of the average value of the water rise level during the year (May 1973 December 2012).

Calculations of the flooded area were adjusted taking into account data from the Central Office of the Russian Ministry of Emergency Situations in Krasnoyarsk Krai on the size of the area flooded from 2000 to 2018, as well as data received from the Federal State Budgetary Institution "Middle Siberian Department for Hydrometeorology and Environmental Monitoring".

The boundaries of flooded areas have been determined in case of floods with congestion (retaining water levels) of $1 \%$ of the estimated frequency and their territories in case of floods with congestion of $3 \%, 5 \%, 10 \%, 25 \%, 50 \%$ of the estimated frequency.

Table 3 shows the areas of flood zones and their territories within the boundaries of Yartsevo. 
Table 3. Area of flooded zones and their territories in case of flooding with surface water.

\begin{tabular}{|l|l|l|}
\hline No. & \multicolumn{1}{|c|}{ Area of flooded zones and their territories } & Area, $\mathbf{k m}^{2}$ \\
\hline 1. & $\begin{array}{l}\text { Flooded zone adjacent to the unregulated Yenisey River, territories are flooded } \\
\text { in the event of floods with 1\% estimated frequency (repeatability once every } \\
100 \text { years) }\end{array}$ & 3.775 \\
\hline 2. & $\begin{array}{l}\text { Territories in the flooded zone in the event of floods with 3\% estimated } \\
\text { frequency }\end{array}$ & 3.595 \\
\hline 3. & $\begin{array}{l}\text { Territories in the flooded zone in the event of floods with 5\% estimated } \\
\text { frequency }\end{array}$ & 3.298 \\
\hline 4. & $\begin{array}{l}\text { Territories in the flooded zone in the event of floods with } 10 \% \text { estimated } \\
\text { frequency }\end{array}$ & 1.871 \\
\hline 5. & $\begin{array}{l}\text { Territories in the flooded zone in the event of floods with } 25 \% \text { estimated } \\
\text { frequency }\end{array}$ & 1.008 \\
\hline 6. & $\begin{array}{l}\text { Territories in the flooded zone in the event of floods with } 50 \% \text { estimated } \\
\text { frequency }\end{array}$ & 0.462 \\
\hline
\end{tabular}

It is worth mentioning that modelling of waterlogging, which is caused by rising water flood of the river, requires a joint accounting of the processes of flooding and underflooding. The complex topography of the floodplain and the high permeability of the ground in the area of water exchange, even with flood protection, also necessitate accounting for the ground water outcrop on the surface of the protected area.

As a result of modelling the waterlogged area within the boundaries of Yartsevo the following results were obtained:

a) areas of high waterlogging (with groundwater depths of less than $0.3 \mathrm{~m}$ );

b) areas of moderate waterlogging (with groundwater depths of $0.3-0.7$ to $1.2-2.0 \mathrm{~m}$ from the surface);

c) areas of weak waterlogging (with groundwater depths of 2.0 to $3.0 \mathrm{~m}$ ).

Modelling of changes in groundwater levels is carried out within an annual period with a dispersion from a few days to decades for cases of presence and absence of high water flooding. In the latter case, the water levels of the Yenisey River are assumed to be constant throughout the year and equal to the minimum levels of the calculated schedule for the year with abundance of water.

The calculated surface of maximum ground water levels in a settlement in the year of floods with $1 \%$ estimated frequency is compared to the surface of maximum ground water levels in case of absence of flood impact. However, an area where the difference in levels does not exceed $0.1 \mathrm{~m}$ is neglected when determining the area of flooding induced by the river.

Table 4 shows the areas of waterlogged zones adjacent to the flooded zones of the Yenisey River and their territories within the boundaries of Yartsevo.

Table 4. Setting Word's margins.

\begin{tabular}{|c|l|c|}
\hline No. & \multicolumn{1}{|c|}{ Area of flooded zones and their territories } & Area, $\mathrm{km}^{2}$ \\
\hline 1. & $\begin{array}{l}\text { Flooded zone adjacent to the unregulated Yenisey River, territories are flooded in } \\
\text { the event of floods with } 1 \% \text { estimated frequency (repeatability once every } 100 \text { years) }\end{array}$ & 0.024 \\
\hline 2. & $\begin{array}{l}\text { Areas of high waterlogging at depth of groundwater less than } 0.3 \mathrm{~m} \text { from the } \\
\text { surface in the waterlogged zone }\end{array}$ & 0.003 \\
\hline 4. & $\begin{array}{l}\text { Areas of moderate waterlogging at depth of groundwater less than } 0.3-0.7 \mathrm{~m} \text { to } \\
1.2-2.0 \mathrm{~m} \text { from the surface in the waterlogged zone }\end{array}$ & 0.013 \\
\hline 5. & $\begin{array}{l}\text { Areas of weak waterlogging at depth of groundwater less than } 2.0-3.0 \mathrm{~m} \text { from the } \\
\text { surface in the waterlogged zone }\end{array}$ & 0.008 \\
\hline
\end{tabular}




\section{Conclusion}

Prediction of the risks of intricate, difficult to predict processes arising in social, technical and natural systems, described by incorrect conditions during task-setting, is one of the intensively developing areas of mathematical modelling.

The results of the work present a complex of solutions that allow researchers to enhance the efficient functioning of the system of forecasting the situation of emergencies of natural character through the use of new methods of data collection and processing in different systems of observation and control of the situation.

There was suggested a concept of creating a methodology for predicting flood emergencies using intelligent data analysis technologies. The volume and composition of available information resources make it possible to create software modules for short-term forecasts of water levels and assessment of possible consequences.

As a result of modelling and identification of flood zones, work on bank protection was carried out in the area of the Yartsevo settlement in 2020 in preparation for a flood-prone period, which made it possible to avoid surface water flooding (waterlogging) of economic infrastructure and residential buildings.

In the aftermath of the work performed, methods of mathematical modelling of the determination of flooded areas were demonstrated. The work carried out led to reducing the risk of flooding economic infrastructure and residential buildings in Yartsevo in 2020 during the rising flood water through preventive measures to protect the settlement. The results of this work can be used for modelling in other flood-prone areas.

\section{References}

1. A.M. Vladimirov, Factors determining the occurrence of the extreme flow discharge and the flood water levels, Bulletin of the Russian Academy of Sciences,. №9. Pp. 3-6 (2012)

2. V.A. Akimov, R.A. Durnev, Yu.I. Sokolov, Hydrometeorological Hazards in Russia, EMERCOM of Russia. Moscow: All-Russian Research Institute for Civil Defence and Emergency Situations, 316 p (2009)

3. V.A. Akimov, R.A. Durnev, Yu.I. Sokolov, Protection of the population and territories of the Russian Federation in the context of climate change, EMERCOM of Russia Moscow: All-Russian Research Institute for Civil Defence and Emergency Situations,. 388 p (2016)

4. V.E. Levkevich, A.M. Lepikhin, V.V. Moskvichev, V.G. Nikitenko, V.V. Nicheporchuk, N.Ya. Shaparev, Yu.I. Shokin, Safety and risks of sustainable development of territories, Krasnoyarsk: Siberian Federal University, 224 p (2014)

5. V.V. Moskvichev, Anthropogenic and natural risks in Siberia, Bulletin of the Russian Academy of Sciences, №2. Pp.131-140 (2012)

6. A.V. Korobko, T.G. Penkova, V.V. Nicheporchuk, Operational analytical control of the technosphere and environmental objects condition in the Krasnoyarsk Krai on the basis of the monitoring data, Monitoring. Science and security, №3 (11),. Pp. 66-84 (2013)

7. D.A. Burakov, V.F. Kosmakova, I.N. Gordeev, On the results of the operational tests of the hydrological forecast methods on the East Siberian rivers during the spring flood, Test results of the new and improved technologies, models and methods of hydrological forecasts, № 42. Pp. 50-59 (2015) 
8. Ya.V. Grebnev, A.V. Yarova, Monitoring and flood forecasting in the Krasnoyarsk Krai using the neural network algorithms, Scientific-analytical journal "Siberian Fire and Rescue Bulletin”, №3. Pp.13-16 (2018)

9. V.R. Bolov, A.A. Bykov, V.A. Vladimirov, S.L. Didenko, Yu.I. Sokolov, M.I. Faleev, Modern systems for monitoring and forecasting of emergency situations, Moscow: EMERCOM of Russia, 351 p (2013)

10. T. Penkova, V. Nicheporchuk, A. Metus, Comprehensive Operational Control of the Natural and Anthropogenic Territory Safety Based on Analytical Indicators, International Joint Conference, IJCRS 2017. Olsztyn, Poland, July 3-7, Proceedings, Part I. Pp. 263-270, DOI 10.1007/978-3-319-60837-2 (2017)

11. I.O. Starodumov, St. Venant Kinematic Equation. Solution method, Bulletin of the Adyghe State University, Series 4: Natural, mathematical and technical sciences, No. 2 (137), Pp. 37-43 (2014)

12. M.G. McDonald, A.W. Harbaugh, The History of MODFLOW, Ground Water 41 (2): 280-283. doi:10.1111/j.1745-6584.2003.tb02591.x. PMID 12656294 (2003)

13. C. Milzow, W. Kinzelbach, Accounting for subgrid scale topographic variations in flood propagation modeling using MODFLOW, Water Resour. Res., 46. W10521. doi:10.1029/2009WR008088 (2010)

14. V.M. Lomakin, V.A. Mironenko, V.M. Shestakov, Numerical modelling of geofiltration, Moscow: Nedra (1988)

15. B.M. Ginzburg, S.V. Borshch, N.D. Efremova, Methods of background long-term and medium-term forecast of the perioids of the breakup of the rivers of the European territory of Russia, Meteorology and hydrology, № 11 Pp. 67-78 (2001) 